\title{
Practice on Talent Training Mode Aiming at Improving Enrollment and Ability \\ Jing Lin
}

\begin{abstract}
Sub-Institute of Science Technology and Art, Jingdezhen Ceramic Institute, Jingdezhen, Jiangxi, China, 333000

shenghong666@163.com
\end{abstract}

\begin{abstract}
Keyword: Independent institute; Business English; Curriculum; Educational revolution; Ability to work
\end{abstract}

\begin{abstract}
This essay discusses deeply the revolutionary path to the set of business lessons aiming at improving enrollment and ability for English majors of independent institute, according to the characteristics and regulations of business English lessons in independent institute, and changes they made meet the demand of regional construction of economy and society.
\end{abstract}

\section{Introduction}

Since joining the WTO in 2001, Chinese foreign trade has boomed, especially after the New Foreign Trade Law being published out, therefore, the demands for specific people who are able to use English to communicate and negotiate while knowing the regulation of international trade are increasing. According to the agreement of WTO, many trades in China have been opened to foreign world, and it's another golden time for international trading in China. To keep pace with it, the frequency of recruiting English-specific people increases. The most precious ones are people who master English and meanwhile understand the international business. The forecast of needing for professionals released by Ministry of Business shows that, there're 6 types of people are needed the most: international business, international investment, intern ational selling, international negotiation, and international finance. It's obvious that educating professional people with high-quality is one of important elements for companies to take part in internationally competitions, which brings us chances and challenges at the same time. The teaching mode of professional English in China is now out of date, the conflict between demand and education is standing out. On the one hand, professional people who are able to master English, communication skills, knowledge of international business, and business English are in shortage; on the other hand, $30 \%$ university graduates who lost their jobs are from the subjects of English, Computer, Law, and some minorities according to the newest survey from 3 generation of university graduates, made by a 3rd party investigation company Max. It's an urgent thing to refine the mode of education in English now.

Recent years, the researches on business lessons under the major of English focus on First Tier, Second Tier and some professional school. However, business lessons under the major of English in 315 independent institutes, which take about 33\% of high-level universities, are hardly discussed. The curriculum for English majors, especially whose direction is business English, are almost the same, there's no goal which is aiming at educating professional people, and there's no specific curriculum for students with different levels, demands, conditions in independent institutes. So with the leading of social demand, the new revolution of increasing the ability to enroll and innovate in independent institutes is necessary.

\section{The Contains of Talent Training Mode Aiming at Improving Enrollment and Ability}

In the phrase "business English", the meaning of the word "business" is not only business cases or company, but also includes all non-private activities about trading, including trading, finance, management, selling, traveling, law, logistics, maritime affairs, and so many economic, political, social activities carried on around trade and investments.

Therefore, when it comes to practice, we strengthen our power to reform the curriculum of English subject, and are showed below: 
Adapting itself to the growing pace of economy and society; refining the catalog of English major; establishing a system of trimming; promoting the reform of education to practical, skillful, comprehensive people; strengthening the practical teaching, making internship harder; arranging graduates to attend internship; founding intern base with companies and government; Aiming at increasing the enrollment, conducting the mode of combining work and study together, and schools and companies together. Furthermore, double-certifications system is established, too. The overall arrangement of design of business lessons in the English major, highlighting in the characteristics of it. Responding to the economic and social developing strategy made by country and regional government, our college has adapted itself to "the Twelfth Five-year Plan", especially those new demands raised in order to transfer the way our economy developed, and it has already arranged the works of educating corresponding people, and set corresponding majors for emerging industries in advance. It has its own features in English education and corresponding business lessons, effectively increasing graduates' abilities to find a job. Its contains are: the core knowledge of business English; the ability structure of business English; the teaching level of business English; the order of learning business English; the theory base of the set of business English.

\section{Difficult Part of the Revolution}

The set of business English is aiming at train up professional people who have a solid fundament of English, broad international horizon, specific skills and knowledge of business English, the basic knowledge and theory about economy, management, law and other relative subjects, ability to communicate in cross-cultural environment, ability to use English in different situation such as trading, managing and so on. That's why when teaching, teachers tell students about whole sense, and emphasize on the notion of " $1+1>2$ ". As an internationalized professional people, one has to own foreseeing eyes to obey the trend of era, can one become a good player in the work field.

We encounter several obstacles in real life: The thought about education of business English is vague, which lead to many disadvantages in the aspects of measures and curriculum. Traditional English teaching focuses on teaching fundamental and professional knowledge, but ignores the cultivation of their ability to think and practice. Business English, as only a direction of a major, isn't paid enough attention, leading the status quo of its professional lessons take little account and of little depth. It can't meet the demand of our society, and the textbook which is suitable for the lessons in independent institute is in shortage, so is teachers, and the group of teachers are young, but teachers outside are teaching in traditional ways, inflexible and out-date, not to mention their professional knowledge and experiences aren't enough.

\section{The Strategy to Problems}

According to the principle of "wide, solid, qualified, strong", and the post-financial crisis era, and the current circumstance of revolution happens in the area of trading and enrollment, and it is urgently demanded that innovative and comprehensive people be brought up. Our major strengthens the revolution under the guide of "goal of cultivating high-quality, comprehensive, practical people", and the specific measure are:

Tamping Two Fundamental-theory Fundament and English Fundament. Paying more attention to train up the ability to apply English in practice, and connecting 4-year study of English together, and strengthening the study of the second foreign language.

Highlighting the Cultivation of Ability, Deepening the Revolution of Teaching. Combining the cultivation of professional people and the demand of working people closely, perfecting the current system of teaching, which shows the feature of bringing up practical people; It raises the competitive ability of students, and adding demand of ability to the contains of class based on the demand of company. And through the double certification system as "diploma plus certification", speedup the development of construction and revolution, and the construction of the project in our college__English group of ceramic trading", which shows the regional characteristic of training people; starting some new regional lesson, such as "the selected readings of English essays on ceramic", which becomes one of the prescribed lessons in our college and major. This lesson enables students to know about the trading environment and characteristics of this region and 
market, put a solid fundament to the future of students who are going to do trading or financing jobs.

Teaching Practically Applies the Following Procedures. According to the education of theory, deepening the understanding and abstaining of students to the contains of class by task-based teaching and successful and failed examples; Training them to think widely and creatively; arranging internship with the combination of the contains in class; strengthening the practice; helping them to know about the procedure of importing and exporting more directly by arranging a visit to famous foreign company; carrying out colorful activities according to the demand of teaching.

Establishing a System of Practical Teaching, with the Goal of Training Skills, and the comprehensive Training as a Sine Qua non. The Particular Procedure is. Presenting by multi-media, discussing tasks, practicing, training in lab. Conducting a theory of business English, which is led by market and highlighting the ability. It requires us to train people who can use English skillfully when dealing with works about business, trading, managing. Therefore, we stick to the idea of "one core, two characteristics, three abilities" when approaching revolution. One core is to raising the quality and level of teaching in our major by conducting innovation and revolution in objective, methods, curriculum, contains and approaches. Two characteristics are order-like training mode of professional people, which is cooperated by schools and companies; and a special teaching mode of which theory works together with practice, construction of teachers and subjects works together.

Three Abilities are Ability to communicate in the Situation of International Business, Which Means one Can Reach Mutual Understanding between a Country and Another in Trading. the ability to conduct tasks about international business, which means one can do the relative tasks when trading; the ability to managing the international market, which means one owns advanced ideas about international market and knows about the basic method of managing international market, and is good at marketing, managing, analyzing, and making decision.

\section{The Meaning of Revolution}

At improving abilities, obeying the market and perfecting the current curriculum, we have conducted a set of effective plans of education. They are significant for us to improve the enrollment rate, and the competition of students. In macro sense, they help to refresh the theory, method, and contains of teaching, and in that way, school teaching can serve students, and the current society better. Especially when the enrollment rate now is not good, and the demand of a student only know English is zero, the significance of them is particularly of vital urgency

\section{References}

[1] Chen Jiefang. The practice of cooperative education in China-The research on the education mode of combining work and study. Shanghai Jiao Tong University Press, 2006.

[2] Ministry of Education, department of higher education in China and the Academy of Higher Education in China, department of cooperating education. The necessary path-A guide to cooperation in the higher professional schools. Beijing: Higher Education Press

[3] Liu Baocun. The tradition and revolution of theory in universities. Beijing: Education \& Science Press, 2004 